\title{
Moisture dynamic sorption isotherms and thermodynamic properties of parchment specialty coffee (Coffea arabica L.)
}

\author{
Gentil Andres Collazos-Escobar ${ }^{1}$ (iD), Nelson Gutiérrez-Guzmán ${ }^{1}$ (D), \\ Henry Alexander Váquiro-Herrera ${ }^{\text {iD }}$, Claudia Milena Amorocho-Cruz ${ }^{1}$
}

\begin{abstract}
${ }^{1}$ Universidad Surcolombiana, Centro Surcolombiano de Investigación en Café/CESURCAFE, Departamento de Ingeniería Agrícola, Neiva, Colombia ${ }^{2}$ Universidad del Tolima, Facultad de Ingeniería Agronómica, Ibagué, Tolima, Colombia

Contact authors: gentilcollazosescobar09@gmail.com,ngutierrezg@usco.edu.co, havaquiro@ut.edu.co, claudiamilena.amorocho@usco.edu.co Received in November 22, 2019 and approved in July 28, 2020
\end{abstract}

\begin{abstract}
Sorption isotherms represent an efficient and valuable tool for predicting the equilibrium moisture content of foods under different humidities and temperatures; thus, they are useful for determining shelf-life and safe storage conditions. The aims of this study were to determine the sorption isotherms of parchment specialty coffee at water activity values of $0.1-0.8$ and temperatures of 25,30 , and $40{ }^{\circ} \mathrm{C}$ using the dynamic dew point method. The experimental sorption data were modeled using 12 different equations to represent the dependence of equilibrium moisture content on water activity and temperature. Thermodynamic properties were also obtained from the experimental data. The results showed a type II sigmoid shape according to Brunauer-Emmett-Teller (BET) classification, and the double log polynomial (DLP) equation successfully modeled the effects of temperature on the sorption isotherms, obtaining a good fit ( $R^{2}=0.99$ and $R M S E=0.1 \%$ dry basis). The dynamic dewpoint isotherm (DDI) method was advantageous for modelling due to its high availability of experimental data. Thermodynamic analyses showed that the net isosteric heat of sorption, Gibbs free energy, and sorption entropy decreased as equilibrium moisture content increased, and the compensation theory provided evidence that the sorption process was controlled by enthalpy $\left(T_{\beta}>T_{h m}\right)$.
\end{abstract}

Key words: Water activity; equilibrium moisture content; hygroscopicity; non-spontaneous; molecular ordering; compensation theory.

\section{INTRODUCTION}

Coffee is one of the largest globally traded commodities and basic products exported by developing countries (Velasquez et al., 2018). Due to their sensorial attributes, including aroma, body, and reputation, coffees, such as Colombian coffee, have become highly differentiated products (Özdestan et al., 2013). The market for this type of product is constantly growing, driven by changes in consumer preferences (Tolessa et al., 2016). Specialty coffees are characterized as being products with outstanding quality attributes and are generally destined for specialized markets where their prices can reach up to six times those of traditional coffees (Tapiero; Trujillo; Gutiérrez, 2017). To this end, preservation of these desirable sensory qualities is significant and highly dependent on the storage conditions of the coffee (Borém et al., 2013).

Coffee beans are highly hygroscopic, readily absorbing moisture when exposed to the environment during storage (Iaccheri et al., 2015). The moisture content of parchment coffee beans should be 10-12\% wet basis (\% w.b.) for safe, longterm storage (Ghosh; Venkatachalapathy, 2015), and according to the Specialty Coffee Association of America (2019), the water activity $\left(\mathrm{a}_{\mathrm{w}}\right)$ of specialty green coffee beans should be $<0.7$. A moisture content $>12.5 \%$ w.b. creates a number of undesirable consequences, including microbial growth, mycotoxin formation, and an altered sensorial quality of the final product (Barbin et al., 2014), while too low of a moisture content results in weight and economic losses. Therefore, storage conditions represent one of the most important factors in maintaining final product quality (Borém et al., 2013). An important indicator of coffee quality is moisture content, especially in Colombia, where this parameter is difficult to control during storage due to the high humidity of the Central Mountain Range where the majority of Colombian coffee is grown (Donovan; Foster; Parra, 2019).

For proper parchment coffee handling and storage, knowledge of properties such as water sorption isotherms, which describe the relationship between the equilibrium moisture content and the water activity at constant temperature and pressure (Bastioğlu; Koç; Ertekin, 2017), are efficient and valuable tools for the prediction of safe storage (humidity and temperature) conditions and product shelf-life. Another application of sorption isotherms is the calculation of thermodynamic properties useful for estimating energies required for processes related to enthalpy, entropy (excitation states), and Gibbs free energy (spontaneity) (Monte et al., 2018). Isotherms are commonly produced using either a desiccator or climatic chamber in the laboratory (Yin et al., 2018); however, this method is lengthy and introduces possible errors through the combined effects of fungi activity, deterioration reactions, and variations in temperature and humidity during the course of the experiment (Zhang; Sun; Zhang, 2017). These drawbacks have been overcome by the development of automated dynamic water vapor sorption instruments. According to Schmidt and Lee (2012), the advantages of the dynamic dewpoint isotherm (DDI) method compared to the saturated salt slurry isotherm 
method are: increased analysis speed, increased availability of experimental sorption data (often $>75$ data points per isotherm), prevention of microorganism growth, and the opportunity to explore material properties. Furthermore, the sorption isotherms of specialty parchment coffee have yet to be reported.

It is important to understand the hygroscopic properties of dried coffee beans based on their heterogeneous material condition (green versus parchment) to establish the best storage conditions for guaranteed quality, since the initial state of the coffee is the raw material for subsequent stages of coffee processing. The aims of this study were to: 1) determine sorption isotherms at temperatures of 25,30 , and $40{ }^{\circ} \mathrm{C}$ and water activities of 0.1-0.8 using the DDI method; 2 ) evaluate the ability of mathematical models to represent the dependence of the sorption isotherms on water activity and temperature; and 3) determine the net isosteric heat of sorption, Gibbs free energy, sorption entropy, and enthalpy-entropy compensation of dried coffee beans.

\section{MATERIAL AND METHODS}

\subsection{Coffee samples}

Seven specialty coffee samples of Colombia and Castillo variety (Coffea arabica L.), from different farmers from the Huila region of Colombia, were wet processed, and underwent sensory analysis according to the Specialty Coffee Association of America (SCAA) methodology (SCAA, 2015) by four expert panelists at the South Colombian Coffee Research Center (CESURCAFÉ) (Di Donfrancesco; Gutierrez;
Chambers, 2014). The samples, receiving cup scores between 84 and 87.5 , were considered high-quality specialty coffees.

\subsection{Sorption isotherms}

\subsubsection{Initial moisture content}

Moisture content was determined by drying $5 \times 10^{-3} \mathrm{~kg}$ of each sample in an oven (UF55, Memmert GmbH + Co.KG, Schwabach, Germany) at $105^{\circ} \mathrm{C}$ for 24 h (Rendón; Garcia; Bragagnolo, 2014).

\subsubsection{Experimental determinations of the sorption isotherms}

For the development of the DDI method, $3.5 \times 10^{-3} \mathrm{~kg}$ of specialty parchment coffee was placed inside a vapor sorption analyzer (Aqualab VSA, Decagon Devices, Inc., Pullman, WA). Working isotherms were obtained in the water activity range of $0.1-0.8$, at intervals of $0.01 \mathrm{a}_{\mathrm{w}}$, at temperatures of 25,30 , and $40{ }^{\circ} \mathrm{C}$, in triplicate, under an air flow of $6 \mathrm{~L} \mathrm{~h}^{-1}$. The initial moisture content, \% dry basis (\% d.b.), and water activity values were $12 \pm 0.1$ and $0.586 \pm 0.016$, respectively.

\subsubsection{Modelling the sorption isotherms}

The sorption isotherms of the specialty parchment coffee were mathematically represented using twelve models (Table 1), where $\mathrm{X}_{\mathrm{e}}$ is the equilibrium, moisture content (\% d.b.), $a_{w}$ is the water activity, $A, B$, and $C$ are the GuggenheimAnderson-de Boer (GAB) model parameters (Oliveira et al., 2017), $T$ is the absolute temperature $(K)$, and $b_{i}$ are the empirical model parameters.

Table 1: Mathematical models used to represent the specialty parchment coffee sorption isotherms*.

\begin{tabular}{ccc}
\hline Model & Mathematical expression & Reference \\
\hline Modified GAB (1) & $\mathrm{X}_{\mathrm{e}}=\frac{\mathrm{AB}(\mathrm{C} / \mathrm{T})\left(\mathrm{a}_{\mathrm{w}}\right)}{\left[1-\mathrm{B}\left(\mathrm{a}_{\mathrm{w}}\right)\right]\left[1-\mathrm{B}\left(\mathrm{a}_{\mathrm{w}}\right)+\mathrm{B}(\mathrm{C} / \mathrm{T})\left(\mathrm{a}_{\mathrm{w}}\right)\right]}$ & (Oliveira et al., 2017) \\
\hline Oswin (2) & $\mathrm{X}_{\mathrm{e}}=\mathrm{b}_{1}\left(\frac{\mathrm{a}_{\mathrm{w}}}{1-\mathrm{a}_{\mathrm{w}}}\right)^{\mathrm{b}_{2}}$ & (Monte et al., 2018) \\
\hline Smith (3) & $\mathrm{X}_{\mathrm{e}}=\mathrm{b}_{1}+\mathrm{b}_{2} \ln \left(1-\mathrm{a}_{\mathrm{w}}\right)$ & (Shigehisa; Inoue; Kumagai, 2015) \\
\hline Chung-Pfost (4) & $\mathrm{X}_{\mathrm{e}}=\mathrm{b}_{1}+\mathrm{b}_{2} \ln \left(-\ln \mathrm{a}_{\mathrm{w}}\right)$ & (Sormoli; Langrish, 2015) \\
\hline Caurie (5) & $\mathrm{X}_{\mathrm{e}}=\mathrm{exp}\left(\mathrm{b}_{1}+\mathrm{b}_{2} \mathrm{a}_{\mathrm{w}}\right)$ & (Sormoli; Langrish, 2015) \\
\hline Iglesias and Chirife (6) & $\mathrm{X}_{\mathrm{e}}=\mathrm{b}_{1}+\mathrm{b}_{2}\left(\frac{\mathrm{a}_{\mathrm{w}}}{1-\mathrm{a}_{\mathrm{w}}}\right)$ & (Sormoli; Langrish, 2015) \\
\hline White and Eyring (7) & $\mathrm{X}_{\mathrm{e}}=\frac{1}{\left(\mathrm{~b}_{1}+\mathrm{b}_{2} \mathrm{a}_{\mathrm{w}}\right)}$ & (Khawas; Chandra, 2017) \\
\hline Peleg (8) & $\mathrm{X}_{\mathrm{e}}=\mathrm{b}_{0} \mathrm{a}_{\mathrm{w}} \mathrm{b}_{1}+\mathrm{b}_{2} \mathrm{a}_{\mathrm{w}} \mathrm{b}_{3}$ & (Shittu et al., 2015)
\end{tabular}


Table 1: Continuation.

\begin{tabular}{ccc}
\hline Model & Mathematical expression & Reference \\
\hline Kuhn (10) & $\mathrm{X}_{\mathrm{e}}=\left(\frac{\mathrm{b}_{1}}{\ln \mathrm{a}_{\mathrm{w}}}+\mathrm{b}_{2}\right)$ & (Domian et al., 2018) \\
\hline Polynomial (11) & $\mathrm{X}_{\mathrm{e}}=\mathrm{b}_{0}+\mathrm{b}_{1} \mathrm{a}_{\mathrm{w}}+\mathrm{b}_{2} \mathrm{a}_{\mathrm{w}}{ }^{2}+\mathrm{b}_{3} \mathrm{a}_{\mathrm{w}}{ }^{3}$ & (Mousa et al., 2012) \\
\hline Yanniotis and Blahovec (12) & $\mathrm{X}_{\mathrm{e}}=\frac{\mathrm{a}_{\mathrm{w}}}{\mathrm{b}_{0}+\mathrm{b}_{1} \mathrm{a}_{\mathrm{w}}}+\frac{\mathrm{a}_{\mathrm{w}}}{\mathrm{b}_{2}+\mathrm{b}_{3} \mathrm{a}_{\mathrm{w}}}$ & (Bensebia; Allia, 2016) \\
\hline
\end{tabular}

*In all cases, a linear dependence of temperature on the $b_{i}$ parameter was assumed $\left(b_{i} T+b_{i 1}\right)$ (Collazos-Escobar; Gutiérrez-Guzmán; Vaquiro, 2019).

\subsubsection{Parameter estimations and statistical analyses}

MATLAB R2019b (The MathWorks Inc., Natick, MA) was used to identify the model parameters and calculate the $95 \%$ confidence intervals of the parameters of the non-linear regression analyses. The adjusted coefficient of determination $\left(\mathrm{R}_{\text {adj }}^{2}\right)$ and root mean square error (RMSE\%) in percentage (Equation 13), were used to determine the goodness of fit of the statistics, with high $\mathrm{R}_{\text {adj }}^{2}(>0.98)$ and low RMSE $(<10 \%$ d.b.) values considered to be a reasonable fit (Sormoli and Langrish, 2014; Bastioğlu et al., 2017).

RMSE $\%=\sqrt{\frac{1}{N} \sum_{i=1}^{N}\left(X_{\text {exp }}-X_{\text {est }}\right)^{2}} \times 100$

Where $\mathrm{X}_{\text {exp }}$ and $\mathrm{X}_{\text {est }}$ are the experimental and estimated equilibrium moisture content ( $\%$ d.b.), respectively. $\mathrm{N}$ is the number of experimental data points.

\subsection{Fourier-transform infrared (FTIR) spectroscopy}

To obtain biochemical fingerprints of the coffee samples, an FTIR spectrophotometer (Cary 630, Agilent Technologies, Santa Clara, CA) was used. Attenuated total reflectance (ATR)FTIR measurements were performed under dry atmospheric and room temperature $\left(20 \pm 0.5^{\circ} \mathrm{C}\right)$ conditions (Bahamon; Parrado; Gutiérrez-Guzman, 2018). The dried coffee beans were threshed and ground separately. The ground green and parchment coffee beans $\left(5 \times 10^{-4} \mathrm{~kg}\right)$ were then placed in the sampling accessory and pressed. Background measurements were obtained from readings of the accessory without sample. All the spectra were recorded within the range of $4000-650 \mathrm{~cm}^{-1}$, using an $8 \mathrm{~cm}^{-1}$ resolution, scan rate of 20 , and background correction. All samples were analyzed in triplicate.

\subsection{Thermodynamic properties}

Thermodynamic properties were calculated from the experimental moisture sorption isotherm data. The net isosteric heat of sorption, or enthalpy of sorption, $\left(\mathrm{q}_{\mathrm{sn}}\right)$, was calculated using the Clausius-Clapeyron equation (Equation 14) using the slope of the plot of $\ln \left(\mathrm{a}_{\mathrm{w}}\right)$ versus $1 / \mathrm{T}$ (Domian et al., 2018). The $\mathrm{q}_{\mathrm{sn}}$ was also calculated by integrating Equation 14 between two temperatures (Equation 15). Gibbs free energy $(\Delta \mathrm{G})$ was obtained using Equation 16, and the entropy of sorption $(\Delta \mathrm{S})$ was calculated using Equation 17.

$\mathrm{q}_{\mathrm{sn}}=\mathrm{R}\left[\frac{\mathrm{T}_{1} \mathrm{~T}_{2}}{\mathrm{~T}_{2}-\mathrm{T}_{1}} \ln \frac{\mathrm{a}_{\mathrm{w} 2}}{\mathrm{a}_{\mathrm{w} 1}}\right]$

$\mathrm{q}_{\mathrm{sn}}=-\mathrm{R}\left[\frac{\partial\left(\ln \mathrm{a}_{\mathrm{w}}\right)}{\partial\left(\frac{1}{\mathrm{~T}}\right)}\right]_{\mathrm{X}_{\mathrm{e}}}$

$\Delta \mathrm{G}= \pm \mathrm{RT} \ln \left(\mathrm{a}_{\mathrm{w}}\right)$

$\Delta \mathrm{S}=\frac{\mathrm{q}_{\mathrm{sn}}-{ }_{\Delta \mathrm{G}}}{\mathrm{T}}$

where, $\mathrm{a}_{\mathrm{w}}$ is water activity; $\mathrm{R}$ is the universal gas constant of water vapor $\left(8.314 \times 10^{-3} \mathrm{~kJ} \mathrm{~mol}^{-1} \mathrm{~K}^{-1}\right)$; and $\mathrm{T}$ is the absolute temperature $(\mathrm{K})$.

\subsection{Compensation theory}

According to Červenka, Hloušková and Žabčíková (2015), the enthalpy-entropy compensation theory assumes a linear relationship between $\mathrm{q}_{\mathrm{sn}}$ and $\Delta \mathrm{S}$, as shown in Equation 18 .

$\mathrm{q}_{\mathrm{sn}}=\mathrm{T}_{\beta} \Delta \mathrm{S}+\Delta \mathrm{G}$

where, $T_{\beta}$ is the isokinetic temperature $(K)$. If $T_{\beta}$ is greater than the harmonic temperature $\left(\mathrm{T}_{\mathrm{hm}}\right)$, the sorption process is enthalpy driven; otherwise, the process is considered to be entropy controlled (Bensebia; Allia, 2016). $\mathrm{T}_{\mathrm{hm}}$ was calculated by Equation 19 where $n_{t}$ is the total number of isotherms.

$\mathrm{T}_{\mathrm{hm}}=\frac{\mathrm{n}_{\mathrm{t}}}{\sum_{\mathrm{i}=1}^{\mathrm{n}_{\mathrm{t}}}\left(\frac{1}{\mathrm{~T}_{1}}\right)}$

\section{RESULTS AND DISCUSSION}

Table 2 shows the four mathematical models which best fit the results considering the effects of temperature on the sorption isotherms. 
Table 2: Estimated model parameters and statistical results

\begin{tabular}{|c|c|c|c|c|}
\hline Models & Parameters & Confidence Intervals (95\%) & $\mathrm{R}_{\text {adj }}^{2}$ & RMSE (\% d.b.) \\
\hline $\begin{array}{c}\text { GAB } \\
\text { Modified }\end{array}$ & $\begin{array}{c}\mathrm{A}=11.7 \% \mathrm{~d} . \mathrm{b} . \\
\mathrm{B}=0.154 \\
\mathrm{C}=4.391 \times 10^{4} \mathrm{~K}^{-1}\end{array}$ & $\begin{array}{c}{[11.5 ; 11.9]} \\
{[0.134 ; 0.174]} \\
{\left[4.095 \times 10^{4} ; 4.688 \times 10^{4}\right]}\end{array}$ & 0.918 & 0.3 \\
\hline $\begin{array}{c}\text { Yanniotis and } \\
\text { Blahovec }\end{array}$ & $\begin{array}{c}\mathrm{b}_{3.1}=308.1 \\
\mathrm{~b}_{3}=-0.969 \mathrm{~K}^{-1} \\
\mathrm{~b}_{2.1}=-211.6 \\
\mathrm{~b}_{2}=0.726 \mathrm{~K}^{-1} \\
\mathrm{~b}_{1.1}=21.38 \\
\mathrm{~b}_{1}=-0.033 \mathrm{~K}^{-1} \\
\mathrm{~b}_{0.1}=-2.75 \\
\mathrm{~b}_{0}=9.675 \times 10^{-3} \mathrm{~K}^{-1}\end{array}$ & $\begin{array}{c}220.9 ; 395.4] \\
{[-1.256 ;-0.682]} \\
{[-270.8 ;-152.4]} \\
{[0.524 ; 0.928]} \\
{[16.69 ; 26.06]} \\
{[-0.048 ;-0.018]} \\
{[-3.429 ;-2.071]} \\
{\left[7.404 \times 10^{-3} ; 0.011\right]} \\
\end{array}$ & 0.989 & 0.1 \\
\hline Polynomial & $\begin{array}{c}\mathrm{b}_{3.1}=4.258 \\
\mathrm{~b}_{3}=-0.013 \mathrm{~K}^{-1} \\
\mathrm{~b}_{2.1}=-6.443 \\
\mathrm{~b}_{2}=0.02 \mathrm{~K}^{-1} \\
\mathrm{~b}_{1.1}=2.462 \\
\mathrm{~b}_{1}=-7.371 \times 10^{-3} \mathrm{~K}^{-1} \\
\mathrm{~b}_{0}=0.068\end{array}$ & $\begin{array}{c}{[3.898 ; 4.618]} \\
{[-0.014 ;-0.012]} \\
{[-6.837 ;-6.049]} \\
{[0.018 ; 0.021]} \\
{[2.358 ; 2.566]} \\
{\left[-7.71 \times 10^{-3} ;-7.032 \times 10^{-3}\right]} \\
{[0.067 ; 0.069]}\end{array}$ & 0.986 & 0.1 \\
\hline DLP & $\begin{array}{c}\mathrm{b}_{3}=-5.347 \times 10^{-3} \\
\mathrm{~b}_{2}=-3.876 \times 10^{-5} \mathrm{~K}^{-1} \\
\mathrm{~b}_{1.1}=0.165 \\
\mathrm{~b}_{1}=-6.035 \times 10^{-4} \mathrm{~K}^{-1} \\
\mathrm{~b}_{0.1}=0.279 \\
\mathrm{~b}_{0}=-5.5 \times 10^{-4} \mathrm{~K}^{-1}\end{array}$ & $\begin{array}{c}{\left[-5.694 \times 10^{-3} ;-5 \times 10^{-3}\right]} \\
{\left[-4.004 \times 10^{-5} ;-3.747 \times 10^{-5]}\right.} \\
{[0.158 ; 0.171]} \\
{\left[-6.245 \times 10^{-4} ;-5.825 \times 10^{-4}\right]} \\
{[0.274 ; 0.283]} \\
{\left[-5.644 \times 10^{-4} ;-5.355 \times 10^{-4}\right]}\end{array}$ & 0.99 & 0.1 \\
\hline
\end{tabular}

As shown in Table 2, the DLP model displayed the best representation of the sorption phenomenon of the specialty parchment coffee at water activities of $0.1-0.8$ and temperatures of 25,30 , and $40{ }^{\circ} \mathrm{C}$. This model had a high $\mathrm{R}_{\text {adj }}$ (0.99) and low RMSE ( $0.1 \%$ d.b.) value, confidence intervals showed that all parameters of the model were statistically significant at a confidence level of $95 \%$, and this model was practical for predicting the equilibrium moisture content at all experimental conditions. The DLP model has also been adjusted successfully for use with other agricultural products, including whole black peppercorns (Yogendrarajah et al., 2015) and starch albumen powder (Shittu et al., 2015). The GAB, polynomial, and Yanniotis and Blahovec models had lower goodness of fits compared to the DLP model, although their parameters were statistically significant. The eight additional models (Oswin, Smith, Chung-Pfost, Caurie, Iglesias and Chirife, White and Eyring, Peleg, and Kuhn) showed poor fits compared to the models in Table 2, having lower $\mathrm{R}_{\text {adj }}^{2}$ and higher RMSE values, and should therefore not be considered for describing the sorption process of specialty parchment coffee.

The experimental working isotherms and modelled data using the DLP equation at 25,30 , and $40{ }^{\circ} \mathrm{C}$ are shown in Figure 1.

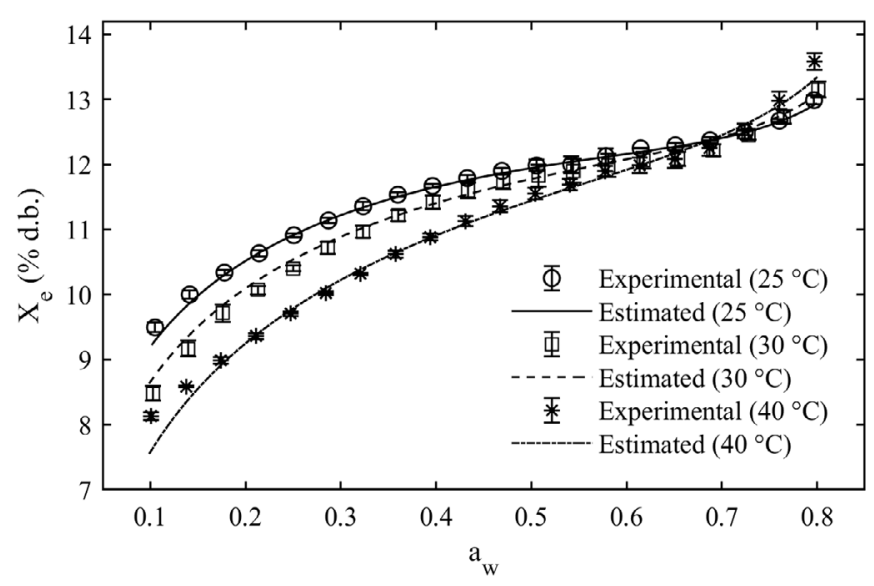

Figure 1: Experimental sorption isotherms and modelled data from the DLP model as a function of equilibrium moisture content at 25,30 , and $40{ }^{\circ} \mathrm{C}$.

As seen in Figure 1, the DLP model well predicts the majority of the experimental data and is highly able to describe the sorption process. The DDI isotherms exhibit a typical type II sigmoid-shape curve according to BET classification, which is characteristic of non-porous and macroporous materials (Inglezakis; Poulopoulos; Kazemian, 2018). This form has also been reported for DDI sorption isotherms of green coffee 
beans (Iaccheri et al., 2015) and green and pulped coffee, and coffee cherry fruit (Corrêa et al., 2010). Similar isotherm forms have also been reported for other agricultural products, including Malaysian paddy (Mousa et al., 2012), rosemary leaves (Bensebia; Allia, 2016), green and roasted yerba mate (Červenka; Hloušková; Žabčíková, 2015), and dry persimmon leaves (Martínez-Las Heras et al., 2014).

All isotherms at the same temperature showed increased equilibrium moisture content with increased water activity. Statistically significant differences $(95 \%)$ in the moisture contents of the isotherms at 25,30 , and $40{ }^{\circ} \mathrm{C}$ for water activity values from $0.1-0.5$ were confirmed by analysis of variance. In the water activity range from 0.5 to $\leq 0.75$, the isotherm representing $40{ }^{\circ} \mathrm{C}$ crossed over, with statistically significant differences $(95 \%)$ not seen again until the $\mathrm{a}_{\mathrm{w}}=0.8$.

It is widely accepted that the effect of temperature increases on sorption isotherms lead to decreases in equilibrium moisture content (Domian et al., 2018). In Figure 1 , for $0.1<\mathrm{a}_{\mathrm{w}}<0.7$, increases in temperature led to decreases in the equilibrium moisture content of the dried coffee beans. This behavior can be explained by the excitation state of water molecules; when temperature is increased the molecules become thermodynamically less stable, leading to a decrease in their attractive forces, thus reducing the moisture content of the product (Monte et al., 2018; Noshad et al., 2012). This sorption behavior has also been reported by Cano-Higuita et al. (2015), Goneli et al. (2013), Mousa et al. (2012), Yogendrarajah et al. (2015), and Bastioğlu et al. (2017).

However, at $\mathrm{a}_{\mathrm{w}} \geq 0.71$, an inverse effect is seen; the equilibrium moisture content increases with increasing temperature, indicating that the product is more hygroscopic. These results can be explained in terms of the solubilization of sugars in foods at high water activity levels and according to Domian et al. (2018), for water activities $>0.7$ water is available as a solvent. Similar trends have been reported for whole black peppercorns (Yogendrarajah et al., 2015), green and roasted yerba mate (Červenka; Hloušková; Žabčíková, 2015), and starch albumen powder (Shittu et al., 2015). The adsorption process was found to be dependent on several highly interrelated factors: the physicochemical properties of the adsorbent (functional groups verified by FTIR spectroscopy), chemical characteristics of the adsorbates, prevailing experimental conditions, and affinity between the adsorbent and adsorbate (Anastopoulos et al., 2017). As seen in Figure 1, the inverse effect of temperature occurs in the region of $\mathrm{X}_{\mathrm{e}}>12.4 \%$ d.b. and $\mathrm{a}_{\mathrm{w}} \geq 0.71$. In order to support the results obtained in Figure 1, spectra of ground green and parchment coffee in the infrared region of $4000-650 \mathrm{~cm}^{-1}$ were obtained (Figure 2).

As shown in Figure 2, the absorbance peaks of the samples can be associated with the chemical compositions of the materials. According to Wei and Tanokura (2015), the composition of green coffee beans is very complex. For example, arabica green coffee beans contain polysaccharides, oligosaccharides, lipids, free amino acids, proteins, chlorogenic acids, caffeine, trigonelline, fatty acids, and minerals. Furthermore, Melo Pereira et al. (2018) reported that green coffee beans contain insoluble (cellulose and hemicellulose) and soluble (arabinose, fructose, galactose, glucose, sucrose, raffinose, and stachyose) carbohydrates. A comparison of the

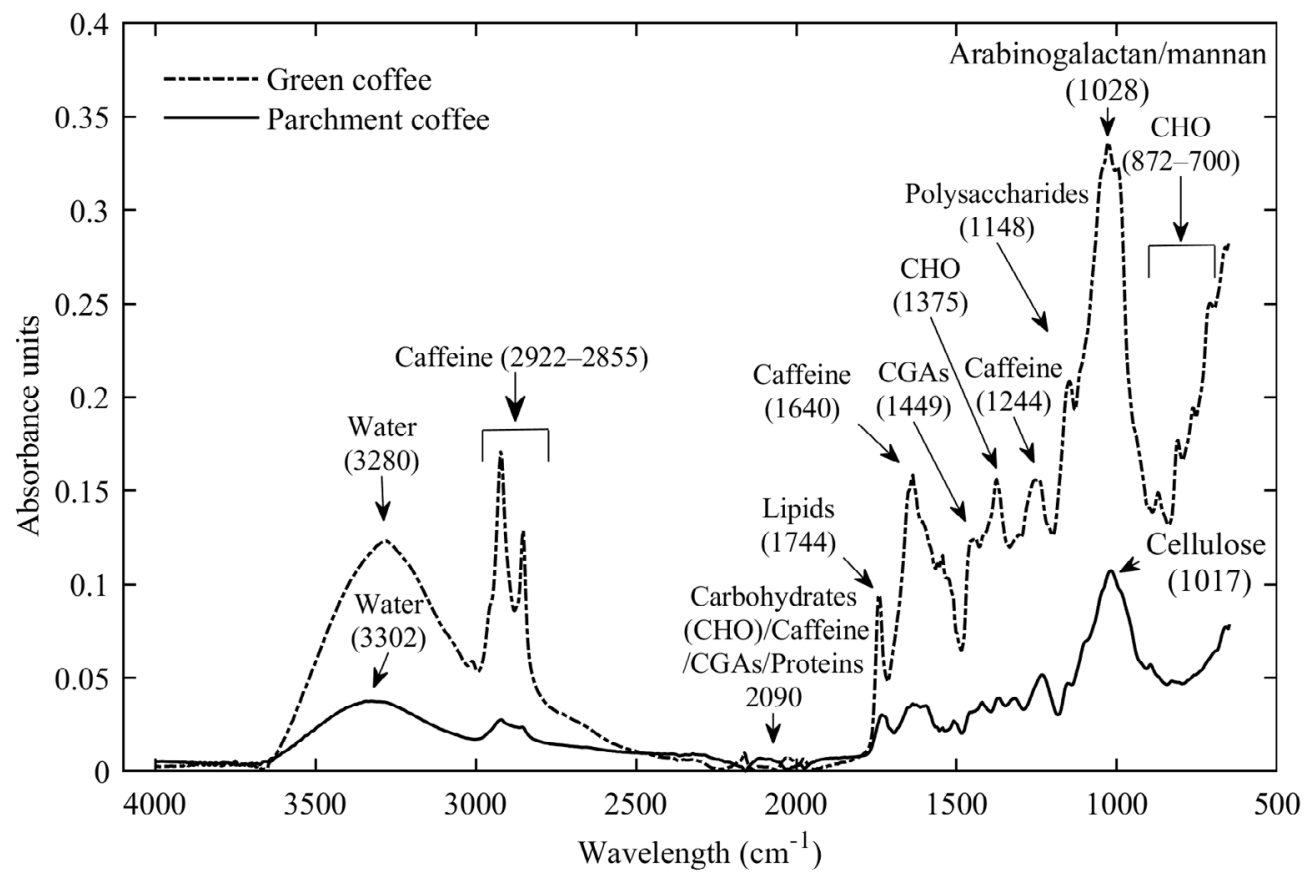

Figure 2: Mean average ATR-FTIR spectra of ground green and parchment coffee $(n=7)$. 
FTIR spectra of green and roasted coffee by Craig, Franca and Oliveira (2012) revealed similar, although different intensity, bands at 2920 and $2850 \mathrm{~cm}^{-1}$ which are associated with caffeine. The band at $1740 \mathrm{~cm}^{-1}$ can be associated with lipids, while the peaks at $1450-1050 \mathrm{~cm}^{-1}$ can partially be attributed to chlorogenic acids (CGAs) (occurring at $1450 \mathrm{~cm}^{-1}$ in this work).

Craig et al. (2018) reported that the arabinogalactan/ mannan fraction of green coffee beans occurs at 1066 and 1034 $\mathrm{cm}^{-1}$ (ring vibration), and caffeine occurs at $1643 \mathrm{~cm}^{-1}$ (observed at 1028 and $1640 \mathrm{~cm}^{-1}$, respectively, in this work). The region near $2100 \mathrm{~cm}^{-1}$ is related to carbohydrates, caffeine, chlorogenic acids, and/or proteins (Craig et al., 2015). The wavelengths of $1700-600 \mathrm{~cm}^{-1}$ can be related to carbohydrates, trigonelline, and chlorogenic acids, while the peak at $1242 \mathrm{~cm}^{-1}$ can be related to caffeine (Craig; Franca; Oliveira, 2012).

Reis, Franca and Oliveira (2013) also mentioned that carbohydrates exhibit several absorption bands in the 1500$700 \mathrm{~cm}^{-1}$ region. For the parchment FTIR spectrum, cellulose exhibits strong bands at 1059 and $1033 \mathrm{~cm}^{-1}$ (ring vibration) (Craig et al., 2018) (presented as a strong peak at $1017 \mathrm{~cm}^{-1}$ in this work) which can be associated with the lignocellulose composition of the parchment (Ramírez-Martínez et al., 2013), being $\sim 57 \%$ cellulose and $\sim 22 \%$ lignin (Collazo-Bigliardi; Ortega-Toro; Chiralt, 2018).

In general, the absorbance values were higher for ground green coffee compared to those of ground parchment coffee. Assuming the parchment coffee is a heterogeneous material, the negative effect of temperature (crossing of isotherms with increased temperature at $\mathrm{a}_{\mathrm{w}}>0.71$ ) may be due to carbohydrate solubility, which also occurs for green coffee. According to Ghosh and Venkatachalapathy (2015), the moisture content of parchment coffee beans should be in the range of $10-12 \%$ w.b.

Using the DLP equation, equilibrium moisture contents at the critical water activity value $\left(\mathrm{a}_{\mathrm{w}}=0.7\right)$, where dissolution occurs and the features of specialty coffee no longer exist, were calculated. These values were: $12.41 \%$ d.b. (11.039\% w.b.) at $25{ }^{\circ} \mathrm{C}, 12.42 \%$ d.b. (11.04\% w.b.) at $30{ }^{\circ} \mathrm{C}$, and $12.45 \%$ d.b. (11.071\% w.b.) at $40{ }^{\circ} \mathrm{C}$. Additionally, at the lowest, safe water activity value $\left(\mathrm{a}_{\mathrm{w}}=0.5\right)$, the equilibrium moisture contents were: $11.94 \%$ d.b. (10.66\% w.b.) at $25{ }^{\circ} \mathrm{C}, 11.78 \%$ d.b. $\left(10.538 \%\right.$ w.b.) at $30{ }^{\circ} \mathrm{C}$, and $11.44 \%$ d.b. (10.265\% w.b.) at $40{ }^{\circ} \mathrm{C}$. Based on these results, to maintain their specialty properties, it is necessary for the coffee samples to be stored in an environment with a relative humidity $(\mathrm{RH}) \geq 50 \%$ but $<$ $70 \%$ at temperatures of $25-40{ }^{\circ} \mathrm{C}$.

Figure 3 shows the plots and slopes of the net isosteric heats of sorption of the dried coffee beans calculated using Equation 14.

The three positive slope values correspond to the crossing isotherm values occurring at water activities $>0.71$. Multiplication of these positive inverse effect values by $-\mathrm{R}$ produces negative net isosteric heat of sorption values (Figure 4A) which are the result of transitions and solubilizations of sugars (Domian et al., 2018). Figure 4 presents the results of the thermodynamic analyses of the specialty parchment coffee.
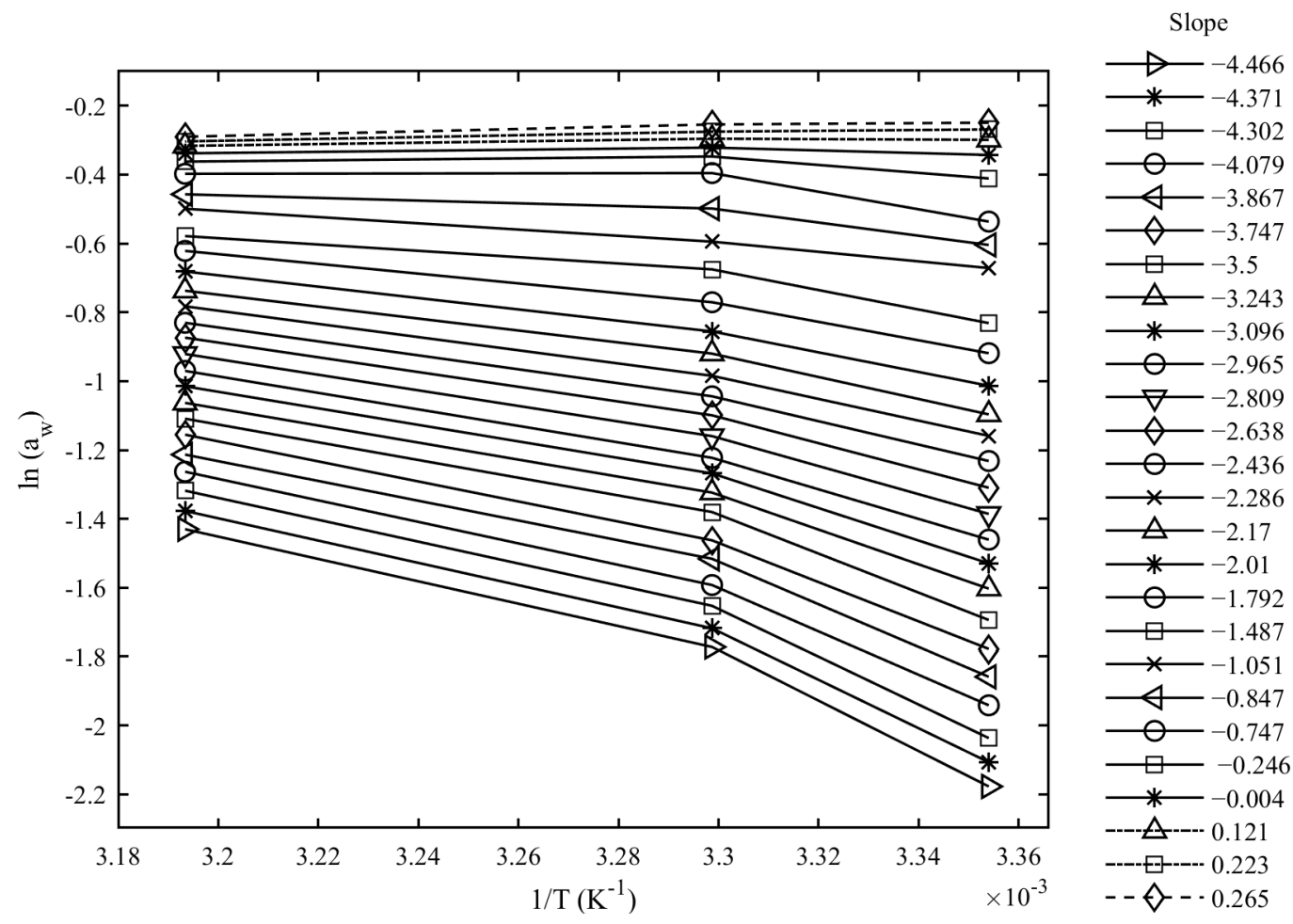

Figure 3: Slopes (Clausius-Clapeyron equation) for the different equilibrium moisture contents of dried coffee beans. 

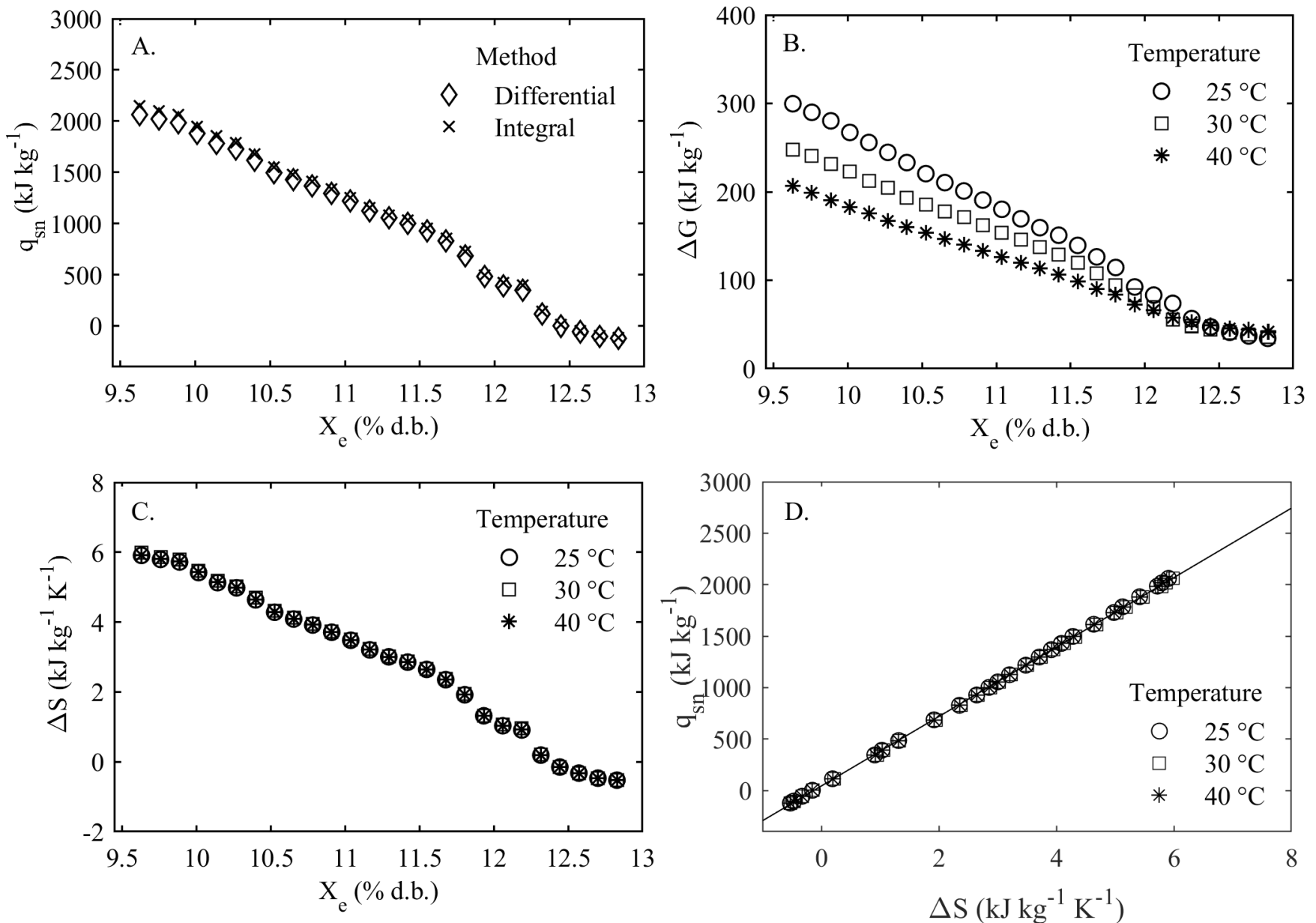

Figure 4: (A) Net isosteric heat of sorption, (B) Gibbs free energy, (C) sorption entropy, and (D) theory of compensation for specialty dried coffee beans as a function of equilibrium moisture content.

The net isosteric heat of sorption provides important information about the energetic changes that occur in food as a function of equilibrium moisture content (Viganó et al., 2012). As seen in Figure 4A, the $\mathrm{q}_{\mathrm{sn}}$ values decreased as the equilibrium moisture content increased. This behavior indicates that sorbent-sorbate interactions are strong at low equilibrium moisture content values and weaken with increasing moisture content. This is due to increases in the equilibrium moisture content leading to active site occupation and sorption occurring at the less active sites, as evidenced by lower heat of sorption values (Noshad et al., 2012).

The results observed in Figure 4A are similar to values reported by Goneli et al. (2013) in green and pulped coffee, and coffee cherry fruits. According to Domian et al. (2018), the negative values of $\mathrm{q}_{\mathrm{sn}}$ at high equilibrium moisture contents can be explained by the inverse effect behavior of the sorption isotherm with temperature, which is due to the solubility of food sugars, and is not normal sorption behavior. The $\Delta \mathrm{G}$ values provide a criterion to evaluate the spontaneous $(\Delta G<0)$ or non-spontaneous $(\Delta G>0)$ nature of water sorption (Bastioğlu et al., 2017), and are related to the amount of energy required to convert water molecules from vapor state to a solid surface, or vice versa (Teixeira; Andrade; Devilla, 2018).

Figure $4 \mathrm{~B}$ shows positive $\Delta \mathrm{G}$ values, indicating that the sorption process was non-spontaneous. According to Goneli et al. (2013), $\Delta \mathrm{G}$ is related to the energy required for the product layers to become available for sorption. At high equilibrium moisture contents, low amounts of energy are required to make the sites available for sorption because they are already available, which is characteristic of an endothermic process. The $\Delta \mathrm{G}$ values obtained using Equation 16 showed similar trends for green coffee at temperatures of 20,30 , and $40{ }^{\circ} \mathrm{C}$ for equilibrium moisture contents of 9.5-12.4\% d.b., except for the last three data points where crossing of $\Delta G$ with temperature occurs.

These values correspond to $a_{w}>0.70$, thus, the results can be explained as being due to the negative effect behavior of temperature on the sorption isotherms. Increases in temperature reduce the amount of energy required to transfer water molecules from solid surface to vapor state, thus reducing the non-spontaneity of the sorption process. This result can be 
explained in terms of the increase in temperature providing kinetic energy to the water molecules (Bastioğlu et al., 2017).

Entropy can be considered in terms of the order/disorder of adsorbed molecules (Cano-Higuita et al., 2015). Figure 4C shows the relationship between sorption entropy and equilibrium moisture content. It can be seen that increases in moisture content lead to decreases in sorption entropy, and the effect of temperature is insignificant. Similar sorption entropy values were reported by Goneli et al. (2013). The negative values of $\Delta S$ at high equilibrium moisture contents can be explained by the inverse effect behavior of the sorption isotherm. This behavior was also reported by Červenka, Hloušková and Žabčíková (2015) in green and roasted yerba mate, and in this work, these values were attributed to the incremental dissolution of sugar with incremental increases in temperature.

The enthalpy-entropy compensation theory was verified. Through linear regression of the data in Figure 4D $\left(\mathrm{R}^{2}\right.$ $=0.9998)$, the $\mathrm{T} \beta$ parameter was $337.5 \mathrm{~K}$ for dried coffee beans. The trendline showed a high level of linearity, indicating that the theory of compensation was most likely valid (Monte et al., 2018). To confirm the compensation theory, a $T_{h m}$ value of $304.69 \mathrm{~K}$ was calculated, showing that $\mathrm{T}_{\beta}>\mathrm{T}_{\mathrm{hm}}$, indicating that enthalpy controls the sorption process, which was supported by the $\Delta \mathrm{G}$ parameter of the linear relationship showing nonspontaneity.

\section{CONCLUSIONS}

The sorption isotherm behavior of the parchment coffee beans exhibited a type II, or S-shaped, form, which is common for non-porous and macroporous food products.

The sorption process was found to be dependent on temperature, with equilibrium moisture content values decreasing with increasing temperature at $\mathrm{a}_{\mathrm{w}}=0.1-0.7$. The DLP model was able to satisfactorily demonstrate the effects of temperature on the sorption isotherms, having a good fit $\left(\mathrm{R}_{\text {adj }}^{2}\right.$ $=0.99$ and $\mathrm{RMSE}=0.1 \%$ dry basis) for specialty parchment coffee at water activities of $0.1-0.8$ and temperatures of 25,30 , and $40{ }^{\circ} \mathrm{C}$. Therefore, the results obtained from this valuable tool are able to accurately predict equilibrium moisture content for establishment of optimal storage conditions of coffee.

The hygroscopic equilibria curves obtained using the DDI method offer a high availability of experimental sorption data, wide working range, and good precision, providing a significant advantage for modelling experimental data. Being detailed and high in resolution, this method can facilitate the adjustment of models to the tendencies of the adsorption/ desorption zones and enable expressions for general conditions representative of sorption phenomena to be obtained.

Water activities $>0.7$ showed possibilities of sugar dissolution and affinity effects between water-coffee, which were verified using ATR-FTIR spectroscopy. These effects led to an inverse effect of temperature (crossing of sorption isotherms), which suggests future research about this widely reported behavior occurring at high levels of water activity should be performed.

Thermodynamic property analyses revealed that net isosteric heat of sorption, Gibbs free energy, and sorption entropy decreased with increasing equilibrium moisture content, providing evidence that the sorption process was nonspontaneous. Enthalpy-entropy compensation theory results suggested that the sorption process was controlled by enthalpy, which corresponds to results previously reported for coffee beans from other cultivars.

\section{ACKNOWLEDGEMENTS}

This work was supported by the South Colombian Coffee Research Center, CESURCAFÉ.

\section{REFERENCES}

ANASTOPOULOS, I. et al. A review for coffee adsorbents. Journal of Molecular Liquids, 229:555-565, 2017.

BAHAMON, M. A. F.; PARRADO, L. X.; GUTIÉRREZGUZMÁN, N. ATR-FTIR for discrimination of espresso and American coffee pods. Coffee Science, 13(4):5505582018.

BARBIN, D. F. et al. Application of infrared spectral techniques on quality and compositional attributes of coffee: An overview. Food Research International, $61: 23-32,2014$

BASTIOĞLU, A. Z.; KOÇ, M.; ERTEKIN, F. G. Moisture sorption isotherm of microencapsulated extra virgin olive oil by spray drying. Food Measure, 11:1295-1305, 2017.

BENSEBIA, O.; ALLIA, K. Analysis of adsorptiondesorption moisture isotherms of rosemary leaves. Journal of Applied Research on Medicinal and Aromatic Plants, 3(3):79-86, 2016.

BORÉM, M. F. Evaluation of the sensory and color quality of coffee beans stored in hermetic packaging. Journal of Stored Products Research, 52:1-6, 2013.

CANO-HIGUITA, D. M. Influence of alternative drying aids on water sorption of spray dried mango mix powders: A thermodynamic approach. Food and Bioproducts Processing, 93:19-28, 2015.

ČERVENKA, L.; HLOUŠKOVÁ, L.; ŽABČÍKOVÁ, S. Moisture adsorption isotherms and thermodynamic properties of green and roasted Yerba mate (Ilex paraguariensis). Food Bioscience, 12:122-127, 2015. 
COLLAZO-BIGLIARDI, S.; ORTEGA-TORO, R.; CHIRALT, B. A. Isolation and characterization of microcrystalline cellulose and cellulose nanocrystals from coffee husk and comparative study with rice husk. Carbohydrate Polymers, 191:205-215, 2018.

COLLAZOS-ESCOBAR, G. A.; GUTIÉRREZ-GUZMÁN, N.; VAQUIRO, H. H. A. Modeling dynamic adsorption isotherms and thermodynamic properties of specialty ground roasted-coffee (Coffee Arabica L.). Coffee Science, 14(1):93, 2019.

CORRÊA, P. C. et al. Moisture sorption isotherms and isosteric heat of sorption of coffee in different processing levels. International Journal of Food Science and Technology, 45(10):2016-2022, 2010.

CRAIG, A. P.; FRANCA, A. S.; OLIVEIRA, L. S. Evaluation of the potential of FTIR and chemometrics for separation between defective and non-defective coffees. Food Chemistry, 132(1):1368-1374, 2012.

CRAIG, A. P. et al. Mid infrared spectroscopy and chemometrics as tools for the classification of roasted coffees by cup quality. Food Chemistry, 245:1052-1061, 2018.

CRAIG, A. P. et al. Fourier transform infrared spectroscopy and near infrared spectroscopy for the quantification of defects in roasted coffees. Talanta, 134:379-386, 2015.

DI DONFRANCESCO, B.; GUTIERREZ, G. N.; CHAMBERS IV, E. Comparison of results from cupping and descriptive sensory analysis of Colombian brewed coffee. Journal of Sensory Studies, 29(4):301-311, 2014.

DOMIAN, E. et al. Effect of carbohydrate type on the DVS isotherm-induced phase transitions in spray-dried fat-filled pea protein-based powders. Journal of Food Engineering, 222:115-125, 2018.

DONOVAN, K. N.; FOSTER, A. K.; PARRA, S. C. A. Analysis of green coffee quality using hermetic bag storage. Journal of Stored Products Research, 80:1-9, 2019.

GHOSH, P.; VENKATACHALAPATHY, N. Changes in physico-chemical properties of coffee due to hot air assisted microwave drying. International Journal of Processing and Post Harvest Technology, 6(1):69-79, 2015.

GONELI, A. L. D. et al. Water sorption properties of coffee fruits, pulped and green coffee. LWT - Food Science and Technology, 50(2):386-391, 2013.

IACCHERI, E. et al. Different analytical approaches for the study of water features in green and roasted coffee beans. Journal of Food Engineering, 146:28-35, 2015.

INGLEZAKIS, J. V.; POULOPOULOS, S. G.; KAZEMIAN, $\mathrm{H}$. Insights into the S-shaped sorption isotherms and their dimensionless forms. Microporous and Mesoporous Materials, 272: 166-176, 2018.

KHAWAS, P.; CHANDRA, D. S. Moisture sorption isotherm of underutilized culinary banana flour and its antioxidant stability during storage. Journal of Food Processing and Preservation, 41(4):e13087, 2017.

MARTÍNEZ-LAS HERAS, R. et al. Moisture sorption isotherms and isosteric heat of sorption of dry persimmon leaves. Food Bioscience, 7:88-94, 2014.

MELO PEREIRA, V. D. et al. Exploring the impacts of postharvest processing on the aroma formation of coffee beans - A review. Food Chemistry, 272:441-452, 2018.

MONTE, L. M. et al. Moisture sorption isotherms of chitosan-glycerol films: Thermodynamic properties and microstructure. Food Bioscience, 22:170-177, 2018.

MOUSA, W. et al. Sorption isotherms and isosteric heats of sorption of Malaysian paddy. J Food Sci Technol, 51(10):2656-2663, 2012.

NOSHAD, M. et al. Desorption isotherms and thermodynamic properties of fresh and osmotic-ultrasonic dehydrated quinces. Journal of Food Processing and Preservation, 37(5):381-390, 2012.

OLIVEIRA, G. H. et al. Roasting, grinding, and storage impact on thermodynamic properties and adsorption isotherms of arabica coffee. Journal of food processing and preservation, 41(2):e12779, 2017.

ÖZDESTAN, Ö. et al. Differentiation of specialty coffees by proton transfer reaction-mass spectrometry. Food Research International, 53(1):433-439, 2013.

RAMÍREZ-MARTÍNEZ, A. et al. Water transport in parchment and endosperm of coffee bean. Journal of Food Engineering, 114(3):375-383, 2013.

REIS, N.; FRANCA, S. A.; OLIVEIRA, S. L. Discrimination between roasted coffee, roasted corn and coffee husks by diffuse reflectance infrared Fourier transform spectroscopy. LWT - Food Science and Technology, 50(3):715-722, 2013.

RENDÓN, M. Y.; GARCIA, S. T. J.; BRAGAGNOLO, N. Impact of chemical changes on the sensory characteristics of coffee beans during storage. Food Chemistry, 147:279-286, 2014. 
SCHMIDT, S. J.; LEE, W. J. Comparison between water vapor sorption isotherms obtained using the new dynamic dewpoint isotherm method and those obtained using the standard saturated salt slurry method. International Journal of Food Properties, 15(2):236-248, 2012.

SHIGEHISA, T.; INOUE, T.; KUMAGAI, H. Mathematical model of water sorption isotherms of UBC. Fuel Processing Technology, 131:133-141, 2015.

SHITTU, T. A. et al. Water vapor adsorption characteristics of starch-albumen powder and rheological behavior of its paste. Nigerian Food Journal, 33(1):90-96, 2015.

SORMOLI, M. E.; LANGRISH, T. A. G. Moisture sorption isotherms and net isosteric heat of sorption for spray-dried pure orange juice powder. LWT - Food Science and Technology, 62(1):875-882, 2015.

\section{SPECIALTY COFFEE ASSOCIATION OF AMERICA} SCAA. Coffee standards, water activity standard. 2019. Available on: https://sca.coffee/research/coffeestandards. Access on: 18 August. 2019

SPECIALTY COFFEE ASSOCIATION OF AMERICA SCAA. Protocols: coffee cupping standards, 2015. Available in: http://scaa. org/?page=resources \&d=cupping-standards. Access in: 22 March. 2019

TAPIERO, S. O.; TRUJILLO, B. D.; GUTIÉRREZ, G. N. Aplicación del proceso analítico jerárquico AHP para definir la mejor taza en evaluación de cafés especiales. Coffee Science, 12(3):374-380, 2017.

TEIXEIRA, P. L.; ANDRADE, E. T. de; DEVILLA, A. I. Isosteric heat, entropy, and Gibbs free energy of pumpkin seeds (Cucurbita moschata). Engenharia Agrícola, 38(1):97-201, 2018.

TOLESSA, K. et al. Prediction of specialty coffee cup quality based on near infrared spectra of green coffee beans. Talanta, 150:367-374, 2016.

VELASQUEZ, S. et al. Determination of the complex permittivity of cherry, pulped, green, and roasted coffee using a planar dielectric platform and a coaxial probe between 0.3 and $6 \mathrm{GHz}$. International Journal of Food Properties, 21:1332-1343, 2018.

VIGANÓ, J. et al. Role of enthalpy and entropy in moisture sorption behavior of pineapple pulp powder produced by different drying methods. Thermochimica Acta, 528:6371,2012 .

WEI, F.; TANOKURA, M. Chemical changes in the components of coffee beans during roasting. In: PREEDY, V. R. Coffee in Health and Disease Prevention, Chapter 10, p.83-91, 2015.

YIN, X. et al. Comparative micro-structure and sorption isotherms of rice straw and wheat straw. Energy and Buildings, 173:11-18, 2018.

YOGENDRARAJAH, P. et al. Moisture sorption isotherms and thermodynamic properties of whole black peppercorns (Piper nigrum L.). LWT - Food Science and Technology, 64(1):177-188, 2015.

ZHANG, L.; SUN, D. W.; ZHANG, Z. Methods for measuring water activity $\left(a_{w}\right)$ of foods and its applications to moisture sorption isotherm studies. Critical Reviews in Food Science and Nutrition, 57(5):1052-1058, 2017. 